\title{
Graduate school preparation from the Ronald E. McNair Postbaccalaureate Achievement Program: A systematic review
}

\author{
Rachel Renbarger \\ Baylor University/ United States
}

\begin{abstract}
Underrepresented students attain a lower proportion of graduate degrees in the United States (US), demonstrating inequity in higher education. The Ronald E. McNair Postbaccalaureate Achievement Program has been providing underrepresented students with supports to increase their ability to attain a graduate degree. A systematic literature review identified that the Ronald E. McNair Post-baccalaureate Achievement Program promotes student growth in personal, social, and academic areas, as well as assist students enter graduate school. Few articles mentioned issues with the program but include students' difficulties with socialization and the transition into graduate school. Limitations of the collected studies and possibilities for future research examining this program are included.
\end{abstract}

Keywords: McNair Scholars Program, systematic review, underrepresented students, doctoral students, graduate students

Many programs have been put in place to increase diversity in graduate education in the United States, but disadvantaged students are still not represented at equitable proportions (Sowell, Allum, \& Okahana, 2015). Students who come from higher family incomes, identify as White, and have parents who graduated from college have been found to have distinct advantages for earning a doctoral degree (Baum \& Steele, 2017; Okahana, Feaster, \& Allum, 2016). One program, the Ronald E. McNair PostBaccalaureate Achievement Program, also called the McNair Scholars Program (MSP), is designed to serve these student groups to increase their number of attained graduate degrees. 


\section{Higher Education Politics \& Economics}

The MSP formally began in 1986 to honor Ronald E. McNair, the second African American to go into space (Dervarics, 1994). McNair, a laser physicist, believed in supporting students from underrepresented backgrounds. McNair tragically died in the Challenger explosion on (Date) (Dervarics, 1994). The MSP focuses on recruiting and preparing highly motivated, disadvantaged undergraduate students for doctoral study (Byrd-Johnson, 2017). Once selected, students receive university support, such as faculty mentorship, and seminars, along with a financial stipend to help students prepare for and enroll in graduate school (Byrd-Johnson, 2017).

The federal government has released nationwide program evaluations of MSP using aggregate quantitative information from institutional reports, yet individual programs have utilized qualitative methods. However, there has not been a synthesis of the program's benefits to underrepresented student populations that incorporates both quantitative and qualitative research. Evaluators for the MSP may face pressure to produce findings that the program is effective, making independent reviewers critical for objective program evaluations (Corcoran, 2017). Systematic reviews work well for this purpose, as these reviews synthesize all of the research on one topic to help readers understand what does or does not work (Booth, Sutton, \& Papaioannou, 2012). Compared to traditional literature reviews, systematic reviews provide a transparent and explicit methodology for collecting the evidence, evaluating the evidence for quality, and synthesizing the findings (Dixon-Woods \& Sutton, 2003; Hammersley, 2003). Therefore, the current study will provide a summary of the rigorous research on MSP's effectiveness in preparing students for getting into graduate school and succeeding while there. From these findings regarding the strengths and weaknesses of the MSP, researchers and higher education practitioners can continue with what works and identify areas for change or additional research.

\section{OVERVIEW OF MCNAIR SCHOLARS PROGRAM}

The MSP is one of the US federal government's TRIO programs designed to increase access to higher education for economically disadvantaged students (Seburn, Chan, \& Kirshstein, 2005), serving approximately 5,200 students at 187 institutions and costing approximately $\$ 45$ million annually (Office of Postsecondary Education, 2018). Institutions of higher education can apply to the federal government for this grant every five years, with grant applications being evaluated on administrators' description of stated student needs, target objectives, plan of operation, quality of key personnel, evaluation plan, and quality of project design (Byrd-Johnson, 2017). The approved institutions serve an average of 28 students total per year (Office of Postsecondary Education, 2016). These institutions typically recruit sophomore students to participate in their junior and senior year or junior undergraduates to participate in their senior year, but any undergraduate students may apply (Seburn et al., 2005). The general goal of the MSP is to prepare students for doctoral study by providing academic support and research opportunities to provide a better understanding of what is required to succeed in graduate school. While the ultimate goal of the MSP is to help students attain a doctoral degree, programs are measured by the number of MSP students who enroll in graduate school and persist while there (Office of Postsecondary Education, 2017b). This means that programs encourage 
students to enroll in any graduate program (masters programs included) as a way to successfully attain an advanced degree, ideally a doctoral degree (Office of Postsecondary Education, 2017c).

\section{Program Activities}

Guidance for students in the program includes evidence-based practices, such as research opportunities with faculty mentors, academic counseling and tutoring, along with graduate school testing and application preparation and seminars (Office of Postsecondary Education, 2017b). According to MSP directors, these seminars may include relevant topics related to academic life, such as fighting the "Imposter Syndrome" (feeling like one does not belong in academia) or finding academic support from members with similar backgrounds (S. Morren, personal communication, June 2018). MSP students also receive a stipend to support research activities and either reduced or eliminated costs for graduate applications and required graduate entrance tests (S. Morren, personal communication, June 2018).

\section{Eligible Students}

Students with a strong desire to attain a doctoral degree must demonstrate high academic achievement and motivation in order to participate in MSP (Humphrey, Carey, \& Mansfield, 2002; Seburn et al., 2005). MSPs must enroll a majority of students who are both first-generation students (neither parent has completed a bachelor's degree) and come from a low-income family (one that has annual income below $150 \%$ of the poverty level) (Seburn et al., 2005). The rest of the students must come from other underrepresented student groups, such as those from a racial/ethnic minority group. Due to a lack of disadvantaged students in science, technology, engineering, or mathematics (STEM), MSPs can also provide priority recruitment to students planning on entering graduate school in one of the STEM areas (ByrdJohnson, 2017). This means that institutions that enroll historically underrepresented STEM students, such as women or those with disabilities, may receive more points toward their MSP grant applications (Byrd-Johnson, 2017). Directors must balance the proportions of student populations when accepting students into the program. While there are no published records of acceptance rates, eligible students must go through a rigorous and formal application process that includes the submission of academic information, personal statements, recommendations, and eligibility information to be selected (S. Morren, personal communication, June 2018).

\section{Previous Research on Effectiveness}

The conclusions about MSP's effectiveness are mixed. The National Academies of Science (2011) touted it as a "promising intervention," (p. 166). Contrary to this, the White House claimed it's only "6 percent effective" (Office of the Press Secretary, 2017). Unfortunately, without explaining the evidence to back up this claim, it remains difficult to know what to believe about the MSP. Larger, comprehensive quantitative reports have stated that $99 \%$ of MSPs had met or exceeded all program 


\section{Higher Education Politics \& Economics}

objectives (Mansfield, Sargent, Cahalan, Belle, \& Bergeron, 2002). These larger reports have included annual program data from most, if not all, programs regarding participants' graduate school enrollment and degree attainment. Specifically focusing on the graduate school enrollment objective, programs had tripled the proportion of bachelor's degree recipients who entered graduate school over the course of three years (Seburn et al., 2005), and a recent meta-analysis has found that students in MSPs have six times the odds of enrolling in graduate school compared to students from similar backgrounds (Renbarger \& Beaujean, 2020). Unfortunately, public program data includes only aggregated quantitative program information that is delayed and difficult to use, making it difficult for independent researchers to evaluate the program as a whole (Renbarger \& Beaujean, 2020). Additionally, no research has collectively examined all of the qualitative evidence that exists on this program in conjunction with these quantitative findings from federal and individual program reports to determine if MSPs are effective. This gap in knowledge makes it impossible for practitioners to know what works and what policy makers should or should not do regarding the continuation of this program. Filling this hole will provide answers for programs, policy makers, and researchers searching for answers regarding the MSP.

\section{Current Study}

Given that there has been no synthesis of the research on MSPs, examining the success of the program in terms of one of its objectives remains important. The research question of this systematic review is: What does the empirical literature report about the effectiveness of MSP on graduate student success? Graduate student success for this study will include preparation for graduate school activities, graduate school application assistance, enrollment or persistence in graduate school, or completion of a graduate degree.

\section{METHOD}

In searching for empirical papers to review, the following terms were used: "McNair," "McNair program," "McNair Scholars Program," "McNair program effectiveness" and "trio program" in the following databases: Academic Search Complete, American Doctoral Dissertations, Education Research Complete, EJournals, ERIC, Humanities Source, MAS Ultra- School Edition, MasterFile Premier, PsycArticles, Psychology and Behavior Sciences Collection, PsycInfo, TOPICSearch, and Google Scholar. Databases were chosen to include a variety of fields and publication types for the goal of finding all available research on this topic. To ensure all possible sources were included in the search, reference lists were examined from MSP articles and contact was made with the US Department of Education (DoE) research analysts and authors of studies with MSP samples for any unobtainable sources or unpublished research. No additional empirical studies were found from contacting these authors.

The literature search began April 2017 and ended September 2018. Initially, all articles with titles or abstracts that specifically mentioned the MSP were selected along with any article that had an abstract that contained descriptions of programs 
similar to the MSP (i.e., "undergraduate research program for underrepresented populations"). The full texts of the publications were then further screened to determine inclusion.

To be included in this systematic review, publications had to be focused on the Ronald E. McNair Post-baccalaureate Achievement Program. Descriptions of the program, opinion editorials, and other types of non-empirical studies were excluded. Studies that focused on similar programs for similar populations were not included. Participants in the studies must have been current or past MSP scholars. Only studies reporting on student outcomes related to graduate school preparation and completion were eligible. Outcomes for students could be qualitative or quantitative in nature and were broadly defined to include bachelor's degree completion, graduate school entry, graduate entrance test preparation, application to graduate programs, perceptions of readiness, and so forth. No study duration or date of publication restrictions were used as the MSP has remained consistent in program offerings since its inception. Additionally, all studies had to be peer-reviewed to be included. Therefore, theses, dissertations, conference papers, or those with unknown sources were removed.

\section{Judging the Quality of Empirical Papers}

There is no consensus among educational researchers as to whether qualitative research can or should be evaluated for quality (Hammersley, 2007), thanks to philosophical (Sparkes \& Smith, 2009), methodological (Freeman et al., 2007), and practical (Barbour, 2001; Hammersley, 2007) issues related to conducting qualitative research. Because of the differences between quantitative and qualitative research approaches, scholars have stated that readers should not rely on specific criteria or checklists to evaluate qualitative research (Barbour, 2001; Davies \& Dodd, 2002; Smith \& Hodkinson, 2005). However, not all research is rigorous, and steps should be taken to ensure that results from low quality articles have been taken into account. As such, each article was evaluated using the criteria for rigor described in the article by Tracy (2010). This included evaluating each qualitative article regarding four major needs: having enough data to support the claims, spending enough time gathering data, using an appropriate sample, and utilizing appropriate data collection and analysis procedures. This meant that authors needed to include data (e.g., interview quotes or survey responses) that directly supported the findings and include specific information about time spent obtaining responses from participants, such as the number of interviews and average length. Studies had an appropriate sample if they sampled MSP participants, directors, or other individuals who could speak to the program and the outcomes. In terms of appropriate data collection and analysis, the authors must have included details about the procedures and provided justification for these methods. The quantitative and mixed methods articles were assessed using the same criteria with the exception of spending enough time gathering the data. If any of the articles had deficiencies in any of the areas, they were excluded from the current study. To further increase the rigor of the current study, all studies were examined and re-examined to find disconfirming information.

\section{Data Analysis}




\section{Higher Education Politics \& Economics}

A thematic analysis approach was used to find themes within the studies. Thematic analysis is a common technique for synthesizing qualitative and quantitative studies, and it involves identifying themes, categorizing study findings within the themes, and summarizing information by theme (Dixon-Woods, Agarwal, Jones, Young, \& Sutton, 2005; Thomas \& Harden, 2008). All studies were read once to understand the scope of the findings and become familiar with the data (Braun \& Clark, 2006). Using an inductive approach, the articles were re-read and initial ideas constructed from two initial codes: academic (school-related) and non-academic (person-related) benefits for students. Additionally, both academic and non-academic outcomes have been shown to affect students' ability to survive and succeed in graduate programs (Sverdlik, Hall, McAlpine, \& Hubbard, 2018) and relate directly to the research questions.

After examining the findings of each article and placing the findings into the two categories, each theme was reviewed. These larger themes were analyzed for smaller components and then named (i.e., "social relationships") to provide specificity for students, administrators, and policymakers. The majority of articles included findings that fit into more than one subtheme; as the increased prevalence suggested reliability of the findings, all common results were woven together to provide a more comprehensive understanding. Articles from each category were read again and summarized to provide a collective understanding of the theme and include differences between them.

\section{RESULTS}

The initial searches resulted in 130 publications. Studies were eliminated if they were duplicates, could not be retrieved, were dissertations or theses, or did not otherwise meet inclusion criteria. The data screening approach, from the initial search procedures through to the final selection of articles, can be seen in Figure 1. Three articles were excluded due to issues with quality. There were four qualitative studies, seven quantitative studies, and one mixed-methods study for a total of 12 articles. The date of these publications had a range of 15 years, from 2001 to 2016 . Four of the 12 were federal reports, and the remaining were journal articles. Publication and sample information, such as the authors, research approach (whether qualitative or quantitative), and main findings, can be found in Table 1. More in-depth characteristics of studies relating to the framework of each study can be found in Table 2. These tables highlight the common characteristics between the studies as well as many of the gaps in the literature. Implications for these gaps in the research are outlined in the discussion section.

The majority of articles examined one institution while the federal reports used data from all MSPs at the time of the study. Samples ranged from 10 to over 12,500 students, and these samples typically included MSP alumni, rather than students currently in the program. However, only two studies sampled MSP alumni who had completed graduate degrees. Three studies only included MSP students from science, technology, engineering, or technology majors. Five studies did not list a specific theoretical lens or framework. Only four studies had similar theoretical frameworks; 
these focused on how students were integrated either social or academically but two focused on undergraduate integration and two focused on graduate school integration.

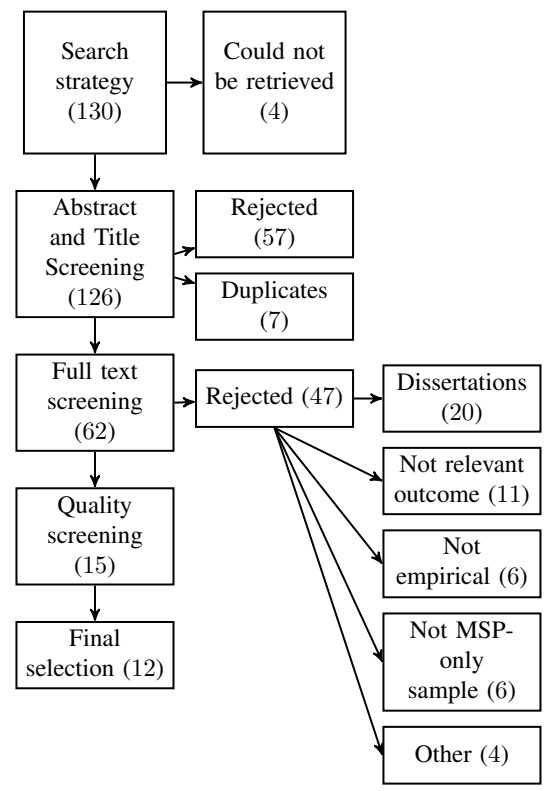

Figure 1. Results from Data Screening Procedures

Two studies, those conducted by Gittens (2014) and Willison and Gibson (2011), should be noted. These studies had been conducted within the last 10 years, utilized a theoretical framework specific for graduate students, and examined graduates' transition into graduate school. These studies sampled students who had completed a graduate degree which allowed for the researchers to examine how the MSP worked to achieve its goal of helping underserved populations attain a graduate degree. However, Willison and Gibson (2011) focused on how these students struggled rather than the strengths of this population, so more work should be done to examine what works for this group.

In answering the question: What does the empirical literature report about the effectiveness of MSP on graduate student success? the literature reported findings related to MSP supporting students prepare for graduate school through academic benefits and non-academic benefits related to social and personal growth. However, these studies also included some obstacles that students faced that provide some additional perspective on the ability of the program to help students succeed (or not) while in graduate school.

Table 1: Publication Information of Included Studies Sorted Alphabetically by Last Name of the First Author 


\section{Higher Education Politics \& Economics}

\begin{tabular}{|c|c|c|c|c|}
\hline $\begin{array}{l}\text { First Author } \\
\text { (Year) }\end{array}$ & $\begin{array}{l}\text { Research } \\
\text { Approach }\end{array}$ & Sample $(n)$ & $\begin{array}{l}\text { Number of } \\
\text { Institutions }\end{array}$ & Major Findings \\
\hline $\begin{array}{l}\text { Bancroft } \\
\text { (2016) }\end{array}$ & $\begin{array}{l}\text { Quantitative- } \\
\text { Descriptive }\end{array}$ & $\begin{array}{l}\text { Current } \\
\text { McNair or } \\
\text { alumni }(n=14) \\
\text { from Ohio } \\
\text { Universities }\end{array}$ & 3 & $\begin{array}{l}\text { Students reported that } \\
\text { their participation in } \\
\text { McNair was positive } \\
\text { in terms of financing, } \\
\text { enrolling in and } \\
\text { interacting with others } \\
\text { in graduate school. } \\
\text { Students also reported } \\
\text { that they felt their } \\
\text { gender and race } \\
\text { impacted their } \\
\text { academic experiences } \\
\text { with peers and faculty. }\end{array}$ \\
\hline Fifolt (2014) & $\begin{array}{l}\text { Mixed } \\
\text { Methods }\end{array}$ & $\begin{array}{l}\text { McNair } \\
\text { alumni }(n=92) \\
\text { from } \\
\text { University of } \\
\text { Alabama at } \\
\text { Birmingham } \\
\text { from years } \\
2007-12\end{array}$ & 1 & $\begin{array}{l}\text { - Students and faculty } \\
\text { mentors expressed } \\
\text { positive interactions } \\
\text { with the mentorship } \\
\text { experience and } \\
\text { progress regarding } \\
\text { research skills. } \\
\text { Students improved } \\
\text { their GRE scores after } \\
\text { attending prep classes } \\
\text { but overall these GRE } \\
\text { scores were not } \\
\text { competitive for } \\
\text { graduate school. } \\
\text { The large majority of } \\
\text { scholars graduated } \\
\text { with their bachelor's } \\
\text { degree. } \\
66 \% \text { of the students } \\
\text { were accepted for } \\
\text { graduate study (doesn't } \\
\text { seem to account for } \\
\text { those that didn't even } \\
\text { apply, though) }\end{array}$ \\
\hline $\begin{array}{l}\text { Gittens } \\
(2014)\end{array}$ & $\begin{array}{l}\text { Qualitative- } \\
\text { Interview } \\
\text { Study }\end{array}$ & $\begin{array}{l}\text { McNair } \\
\text { alumni }(n=18) \\
\text { who } \\
\text { completed } \\
\text { their PhD }\end{array}$ & $\begin{array}{l}1 \\
1\end{array}$ & $\begin{array}{l}\text { Participants believed } \\
\text { that McNair helped } \\
\text { them by learning about } \\
\text { how to apply for } \\
\text { graduate school, } \\
\text { providing an } \\
\text { experience similar to } \\
\text { what they had in } \\
\text { graduate school, and } \\
\text { preparing them for } \\
\text { graduate school } \\
\text { through research } \\
\text { experience and } \\
\text { competence. } \\
\text { In terms of social } \\
\text { integration, students } \\
\text { felt like they belonged }\end{array}$ \\
\hline
\end{tabular}




\begin{tabular}{|c|c|c|}
\hline $\begin{array}{l}\text { Humphrey* } \\
\text { (2002) }\end{array}$ & $\begin{array}{l}\text { Quantitative- } \\
\text { Descriptive }\end{array}$ & $\begin{array}{l}\text { All McNair } \\
\text { students from } \\
1998-2000 \\
(n=10,934)\end{array}$ \\
\hline $\begin{array}{l}\text { Ishiyama } \\
\text { (2003) }\end{array}$ & $\begin{array}{c}\text { Quantitative- } \\
\text { Chi-square } \\
\text { Test }\end{array}$ & $\begin{array}{l}\text { McNair } \\
(n=70) / \text { non- } \\
\text { McNair } \\
(n=240) \text { first } \\
\text { generation and } \\
\text { low-income } \\
\text { students; from } \\
1992-1995\end{array}$ \\
\hline $\begin{array}{l}\text { MacPhee } \\
(2013)\end{array}$ & $\begin{array}{l}\text { Quantitative- } \\
\text { ANOVAs and } \\
\text { MANOVAs }\end{array}$ & $\begin{array}{l}\text { McNair STEM } \\
\text { students } \\
(n=168) \text { over a } \\
10 \text { - year } \\
\text { period }\end{array}$ \\
\hline
\end{tabular}

Mansfield* (2002)

$\begin{array}{cl}\begin{array}{cl}\text { Quantitative- } \\ \text { Descriptive }\end{array} & \begin{array}{l}\text { All alumni } \\ (n=9,090) \text { who }\end{array} \\ & \text { finished } \\ & \text { McNair in }\end{array}$

to a community with important connections and long-term support in a family environment.

- They better knew about what the process was for attaining a $\mathrm{PhD}$.

- It also gave them affective benefits, such as confidence and motivation.

- A quarter to a third of graduated students attended a graduate school the following year.

- $\quad$ The large majority of students who enrolled in graduate school $(91 \%)$ persisted in or graduated from graduate school.

- $\quad$ McNair FGLI students are more likely to persist in and graduate with a bachelor's degree program and were more likely to enroll in graduate school.

- At the beginning of the program, women and men had statistically different levels of academic self-efficacy but similar academic performance.

- $\quad$ By the end of the program, women and men had similar academic self-efficacy.

- Students coming from multiplydisadvantaged backgrounds benefited from the program more in terms of critical thinking and creativity.

- Approximately a third to half of graduates of the McNair program had enrolled in 


\section{Higher Education Politics \& Economics}

1998-1999

year

$\begin{array}{lcl}\text { McCoy* } & \text { Quantitative- } & \text { All McNair } \\ \text { (2008) } & \text { Descriptive and } & \text { Regression } \\ & & \begin{array}{l}(n=12,530), \\ 1989-2003\end{array}\end{array}$

Nnadozie
(2001)

Quantitative-

McNair

Descriptive and

Regression

directors

$(n=35)$ from

across country

and alumni

$(n=69)$
$35 ; 1$

Posselt (2012)

Qualitative-

Current

McNair

students

$(n=10)$
Seburn*

(2005)
Quantitative-

Descriptive
All McNair

bachelor's

recipients graduate school the

following year.

- $\quad$ Approximately $6 \%$ of

McNair alumni had

earned a doctorate

within 6-10 years after

finishing the program.

- $\quad$ There were differences

in doctoral degree

attainment by

background

characteristics such as

low-income or race.

- Important variables for completion included

working fewer than 12

hours as an

undergraduate and

having a helpful

faculty mentor.

Both students and directors reported that research internships were important for graduate school admission.

- Students perceived the research internship as important for obtaining graduate school funding and obtaining a graduate degree.

- $\quad$ Students reported that the program facilitated their skills and knowledge of research and confidence in research and presenting.

- $\quad$ Having group membership within an encouraging cohort provided positive interactions that promoted confidence as well.

- One downside is the fact that it can be intimidating for some students to be a part of a high-achieving, selective group.

- $\quad$ McNair students enrolled in graduate school at higher rates 


\begin{tabular}{|c|c|c|c|c|}
\hline & & $\begin{array}{l}(n=1,282) \\
1998-99\end{array}$ & & $\begin{array}{l}\text { compared to similar } \\
\text { peers. } \\
\text { McNair students were } \\
\text { less likely to persist in } \\
\text { graduate school than } \\
\text { demographically } \\
\text { similar students. }\end{array}$ \\
\hline $\begin{array}{l}\text { Willison } \\
\text { (2011) }\end{array}$ & $\begin{array}{c}\text { Qualitative- } \\
\text { Interview } \\
\text { Study }\end{array}$ & $\begin{array}{l}\text { McNair } \\
\text { alumni }(n=22) \\
\text { who were } \\
\text { enrolled or } \\
\text { graduated } \\
\text { from a } \\
\text { graduate } \\
\text { program }\end{array}$ & 1 & $\begin{array}{l}\text { Students identified } \\
\text { challenges associated } \\
\text { with transitions to } \\
\text { graduate school, } \\
\text { including being } \\
\text { prepared for the } \\
\text { academic workload, } \\
\text { finding emotional or } \\
\text { social support, } \\
\text { managing time well, } \\
\text { feeling accepted within } \\
\text { their programs, and } \\
\text { maintaining finances. }\end{array}$ \\
\hline
\end{tabular}

Note. $*$ indicates the publication was a federal report. The remaining publications were journal articles.

\section{Academic Benefits}

All but one of the studies included academic benefits related to graduate school enrollment, persistence, or completion. For example, studies included research questions related to academic interactions in STEM degree programs (Bancroft, Benson, \& Johnson-Whitt, 2016), the relationship of the rigor of internships on placement into and completion of graduate school (Nnadozie, Ishiyama, \& Chon, 2001), and "student participation in collaborative research projects" on enrolling in graduate school (Ishiyama \& Breuning, 2003, p.163). Each outcome was directly related to the purpose of the MSP.

In terms of pursuing enrollment in a graduate school, studies reported that the MSP showed students how to apply for graduate school (Gittens, 2014), find money for attending school (Bancroft et al., 2016; Nnadozie et al., 2001), and improve their GRE scores (Fifolt, Engler, \& Abbott, 2014). All MSP students are required to complete a summer research internship, participate in research projects with a faculty mentor, and present their findings to other scholars at professional conferences. In a study that examined MSP students' and directors' perceptions of the research internships, both groups believed that these research internships positively related to the students' admission into graduate school (Nnadozie et al., 2001). In terms of the relationship between program participation and actual enrollment, multiple studies identified that a significant portion of alumni from the MSP were likely to be accepted into graduate school overall (Fifolt et al., 2014; Mansfield, Sargent, Cahalan, Belle, $\&$ Bergeron, 2002) and compared to students from similar demographic backgrounds (Ishiyama \& Hopkins, 2003; Seburn et al., 2005).

Students also felt more prepared for graduate school and this was mostly related to their research experiences. Thanks to MSPs, these students believed they had improved research and presenting skills (Fifolt et al., 2014; Gittens, 2014; Posselt \& 


\section{Higher Education Politics \& Economics}

Black, 2012), which made them feel more competent in completing graduate school research (Gittens, 2014). The MSP assisted students in attaining a Ph.D. because they had a better understanding of the process thanks to the program requirements (Gittens, 2014). Mentors also believed that students had positive gains in their researching abilities from their time in the program (Fifolt et al., 2014). Some students even stated that the research internship was important for obtaining the graduate degree (Nnadozie et al., 2001). MSP reports have indicated that a large majority of participants were able to persist and graduate from graduate school (Humphrey et al., 2002), contrary to findings that suggest that MSP students were not as likely to continue their degree progression compared to demographically-similar peers (Seburn et al., 2005). Doctoral degree attainment differed by important demographic variables such as low-income status or race (McCoy, Wilkinson, \& Jackson, 2008).

Outside of academic benefits specifically for graduate school, MSP students also had increased levels of creativity and critical thinking over the course of the program (MacPhee, Farro, \& Canetto, 2013). This was especially true for students who come from more than one underserved background, such as being both low-income and from a minority race.

\section{Non-Academic Benefits}

Non-academic benefits included anything not directly measured by graduate enrollment, persistence, or completion. These included concepts such as social integration- "the means by which a student joins a community and identifies with its values and norms" (Gittens, 2014, p. 365), self-efficacy (MacPhee et al., 2013), and research identities (Posselt \& Black, 2012). These ideas appeared to be by-products of the educational experiences.

\section{Social}

Being in an MSP requires frequent and consistent time with peers from similar backgrounds and with similar future goals. Multiple studies included benefits of the MSP that revolve around the community created with these interactions with mentors, directors, and other students. Through the lens of social integration, Gittens (2014) found that MSPs provided a community and source of support that students could utilize from undergraduate times throughout their graduate school journey (Bancroft et al., 2016; Gittens, 2014). Students could find encouragement and beneficial interactions from their peers (Posselt \& Black, 2012). Students and faculty mentors mentioned how the mentoring relationship was positive (Fifolt et al., 2014).

\section{Personal}

Students also reported personal growth from the work they completed in the program. Time in the McNair Scholars program positively related to students' motivation and their confidence in achieving their goals (Gittens, 2014). One study compared how women and men differed in terms of academic self-efficacy and performance at the beginning and end of the program (MacPhee et al., 2013). These 
researchers found that women in an MSP were able to catch up to their male peers' level of academic self-efficacy by the end of the program (MacPhee et al., 2013).

Table 2: Characteristics of Included Studies Sorted Alphabetically by Last Name of the First Author

\begin{tabular}{|c|c|c|c|c|c|c|c|}
\hline $\begin{array}{l}\text { First } \\
\text { Author } \\
\text { (Year) }\end{array}$ & Theoretical Lens & $\begin{array}{l}\text { Included } \\
\text { MeNair } \\
\text { Alumni? }\end{array}$ & $\begin{array}{c}\text { Included } \\
\text { Alumni } \\
\text { with } \\
\text { Completed } \\
\text { Graduate } \\
\text { Degrees? }\end{array}$ & Longitudinal? & $\begin{array}{l}\text { Completed } \\
\text { Within } \\
\text { Last } 10 \\
\text { Years? }\end{array}$ & $\begin{array}{c}\text { Examined } \\
\text { Graduate } \\
\text { School } \\
\text { Enrollment? }\end{array}$ & $\begin{array}{c}\text { Examined } \\
\text { Graduate } \\
\text { School } \\
\text { Transition? }\end{array}$ \\
\hline $\begin{array}{l}\text { Bancroft* } \\
(2016)\end{array}$ & $\begin{array}{l}\text { Sexism, racism, } \\
\text { stereotype threat }\end{array}$ & $\mathrm{x}$ & & & $\mathrm{x}$ & $\mathrm{x}$ & \\
\hline $\begin{array}{l}\text { Eifolts } \\
\text { (2014) }\end{array}$ & None & & & $\mathrm{x}$ & $\mathrm{x}$ & & \\
\hline $\begin{array}{l}\text { Gittens } \\
\text { (2014) }\end{array}$ & $\begin{array}{l}\text { Graduate and } \\
\text { undergraduate social } \\
\text { and academic } \\
\text { integration }\end{array}$ & $\mathrm{x}$ & $\mathrm{x}$ & & $\mathrm{x}$ & & $\mathrm{x}$ \\
\hline $\begin{array}{l}\text { Humphrey } \\
(2002)\end{array}$ & None & $\mathrm{x}$ & $\mathrm{x}$ & $\mathrm{x}$ & & $\mathrm{x}$ & \\
\hline $\begin{array}{l}\text { Ishiyama } \\
\text { (2003) }\end{array}$ & $\begin{array}{l}\text { Undergraduate } \\
\text { persistence and } \\
\text { academic integration }\end{array}$ & $\mathrm{x}$ & & $\mathrm{x}$ & & $\mathrm{x}$ & \\
\hline $\begin{array}{l}\text { MacPhee*t } \\
(2013)\end{array}$ & Self-efficacy & & & $\mathrm{x}$ & $\mathrm{x}$ & & \\
\hline $\begin{array}{l}\text { Mansfield } \\
(2002)\end{array}$ & None & $\mathrm{x}$ & $\mathrm{x}$ & $\mathrm{x}$ & & $\mathrm{x}$ & \\
\hline $\begin{array}{l}\text { McCoy } \\
(2008)\end{array}$ & None & $\mathrm{x}$ & $\mathrm{x}$ & $\mathrm{x}$ & & $\mathrm{x}$ & \\
\hline \multicolumn{8}{|c|}{ Table 2 continued } \\
\hline $\begin{array}{l}\text { Npadozic } \\
\text { (2001) }\end{array}$ & $\begin{array}{l}\text { Undergraduate } \\
\text { academic integration }\end{array}$ & $\mathrm{x}$ & $\mathrm{x}$ & & & $\mathrm{x}$ & \\
\hline $\begin{array}{l}\text { Passelh } \\
\text { (2012) }\end{array}$ & $\begin{array}{l}\text { Social and cultural } \\
\text { capital }\end{array}$ & & & & $\mathrm{x}$ & & \\
\hline $\begin{array}{l}\text { Sebuaph } \\
\text { (2005) }\end{array}$ & None & $\mathrm{x}$ & $\mathrm{x}$ & $\mathrm{x}$ & & $\mathrm{x}$ & \\
\hline $\begin{array}{l}\text { Willison' } \\
\text { (2011) }\end{array}$ & $\begin{array}{l}\text { Graduate school } \\
\text { integration }\end{array}$ & $\mathrm{x}$ & $\mathrm{x}$ & & $\mathrm{x}$ & & $\mathrm{x}$ \\
\hline
\end{tabular}

Note. * indicates the study only utilized a sample of science, technology, engineering, and mathematics students. $\uparrow$ indicates the study focused on sample deficits

\section{Obstacles}

While the majority of findings from the studies were positive, some studies uncovered obstacles that students faced while in the program and while in graduate school. One study found that students reported that their interactions with other 


\section{Higher Education Politics \& Economics}

students in their academic programs and the faculty there depended on their gender and their race (Bancroft et al., 2016). This is not due to their enrollment in a MSP, but does highlight the need for supporting students who are not highly represented in their programs or fields such as women in STEM or graduate students of color. The main purpose of MSPs is to help minoritized populations get to graduate school but these places may push these students away whether intentionally or not. As such, this program may not be able to help solve this lack of representation alone; systemic change must occur on the other end of the pipeline as well. Disadvantages from participation in MSPs related to adequate progress and social comparison. While one study mentioned that students increased their GRE scores after GRE preparation classes, the students' GRE scores were still not competitive enough for graduate schools (Fifolt et al., 2014). Even for those that enrolled in graduate school, students reported that the transition was difficult. These students did not feel adequately prepared, did not feel like they had a supportive environment, needed help with time management, struggled with finances and did not generally feel accepted (Willison \& Gibson, 2011). Some students also reported that being in such a selective and highachieving group can be intimidating and overwhelming at times (Posselt \& Black, 2012). So, despite the positive nature of academic benefits, and a social community, careful attention must be made to consider how these supports could be made even more beneficial to all students.

\section{DISCUSSION}

This paper systematically reviewed the research on the McNair Scholars Program. Results indicated that the majority of the large number of studies examining this program find the program works to improve the number of minoritized students applying to and enrolling in graduate school. The majority of the articles reported that the MSP helped students with academic benefits before and during graduate school. The program provided students with guidance applying and enrolling in graduate school and their research experiences gave them skills to enter and succeed while in their graduate program. Reports indicated that many students from the MSP did enroll in graduate school at higher rates than their demographically-similar peers, but other reports indicated that graduate degree completion depended on other important variables such as race. Students also stated that they gained non-academic benefits related to social and personal areas of life. Being in the program provided students with a supportive community with mentors and peers while also boosting students' confidence, motivation, critical thinking, and creativity. However, the program was not without its challenges. Students perceived difficulties with social interactions and transitions into graduate school.

\section{Implications}

The findings here have implications for policy, practice, and research. In terms of policy, the large majority of results suggest that the MSP is beneficial for underserved students, both in terms of equipping students to research graduate schools and apply as well as have the skills necessary to balance coursework and 
perform independent research. These tools can be a part of the hidden curriculum that exacerbates the inequality between students from privileged households and those from minoritized backgrounds (Smith, 2013). Because this identifies all of the research, evaluates the research for quality, and summarizes the findings from an independent, critical lens, this adds to the federal reports regarding the effectiveness of the program and supports the continued federal funding by policymakers for this specific program.

These results can support the work of MSP directors and other staff dedicated to supporting these student groups. Directors can take these findings and support their students outside of the typical or required program offerings. For example, not all programs take their students to larger research conferences to present and not all directors individually meet with participants regarding academic or personal issues that students are facing. By providing these opportunities, directors can better facilitate students' academic and mental wellbeing during the stressful time of applying to graduate school. By fostering a community without intimidation, directors can continue to provide students with non-academic benefits that support the goal of graduate school attainment. Besides bringing this program to campus, university staff can provide minoritized populations with these experiences to impact more students with what works. Certain parts of the program - namely the stipend, research experience, and graduate application preparation - should remain required aspects of the MSP as these aspects benefit marginalized students who want to attend graduate school (Carter, 2006; Jones, Barlow, \& Villarejo, 2010). Other undergraduate programs that allow students to participate in similar activities may benefit students if a campus MSP is full or unavailable.

These results also have implications for research. One result of this review is the identification of gaps in the literature and new questions that can only be answered with future studies. How do programs that only provide research opportunities, such as those on individual college campuses without graduate application requirements, differ in terms of educational outcomes compared to programs like MSPs with more robust offerings? How influential is the cohort component of the program, in giving students a community of scholars who are from similar backgrounds? Comparing the outcomes of MSP students with those of students from similar programs with distinct offerings can help identify the most necessary components for graduate school preparation.

Because there were only the federal quantitative reports that examined how MSPs impact students through multiple years after their completion of the MSP, it remains unclear how the program affects students through their entire graduate degree process. The quantitative findings provide some longitudinal results regarding students' attainment, but it is not clear that it is only MSP involvement that affected these students' ability to find success in graduate school. What other resources, such as family members or additional job opportunities, do students utilize? MSPs may help students transition into a master's degree through research skill development and application support, but does it give them the necessary support for students to persist through their doctoral degree? What other processes are in place that may help or hinder these students after they apply to graduate school all the way through their degree attainment? These questions and more cannot be answered from the findings 


\section{Higher Education Politics \& Economics}

in the current literature. Future research could compare quantitative outcomes in a meta-analysis or collate data from multiple programs to address these gaps.

Additionally, more updated research should examine the program as a whole. Research has demonstrated the impact of the economic recession from 2007 to 2010 on higher education (i.e., Barr \& Turner, 2013). Since the last federal government report with all institutional data was released over 10 years ago, an update should be done to examine if the program continues to increase students' graduate enrollment to the same degree. Only one report (McCoy et al., 2008) provided a larger picture of the program and student success through a regression with multiple variables. To do this would require access to annual program information regarding the student characteristics and outcomes that are currently unavailable from the government website. Another option would be to compare university information regarding marginalized student outcomes to the outcomes of MSP alumni. It would also be more robust for future studies to include other variables that are known to impact student success, such as faculty relationships and funding, to better understand the success rates for this group. Providing equivalent data from students from similar backgrounds who did not participate in an MSP would allow researchers to determine specific program effects. As this was the only systematic review of this program, we recommend frequent and comprehensive reviews of long-standing federal programs to provide an overview of all that exists for the taxpayers to read.

Finally, five articles had no theoretical framework identified and only two articles in this sample examined graduate school success through theoretical frameworks designed for the graduate student population. As methodologists Grant and Osanloo (2014) state: "Without a theoretical framework, the structure and vision for a study is unclear, much like a house that cannot be constructed without a blueprint" (p. 13). As such, we not only recommend the use of a framework but one that considers the specific needs of graduate students. While some of the other theories used, such as self-efficacy, stereotype threat, and social capital, certainly apply to graduate students, undergraduate student theories do not apply to those of graduate students (Tinto, 2012). Future research should make sure to include theories that not only apply to the graduate student population, but also to the other identities of McNair alumni, such as first-generation, low-income, or minoritized student frameworks.

\section{Limitations}

Limitations of this review include the type of studies allowed. By removing dissertations and theses and screening all studies for quality indicators, the rigor of these findings increased. However, a large portion of the excluded studies were dissertations or theses; as a consequence, the information here may not reflect all that is known regarding the academic and non-academic benefits of the MSP. The institutions included here may also not reflect the variety of MSPs. The federal reports utilized data from all of institutions at the time of the studies. While this is a strength of the federal reports, the most recent report was published in 2008. Given that programming has remained fairly stable in the program's history, this may only limit 
the generalizability of the findings slightly, although some studies have indicated that the programs do not all offer the same activities (Seburn et al., 2005).

\section{CONCLUSION}

In conclusion, there are not enough studies to determine the effectiveness of the MSP. Of the published and available empirical literature, MSPs do provide benefits to participants in multiple domains, but more research is needed to determine if the program helps students in all stages of the graduate degree process and through doctoral degree attainment.

\section{REFERENCES}

Balz, F. J., \& Esten, M. R. (1998). Fulfilling private dreams, serving public priorities: An analysis of TRIO students' successes at independent colleges and universities. The Journal of Negro Education, 67, 333-345. http://dx.doi.org/10.2307/2668134

Bancroft, S. F., Benson, S. K., \& Johnson-Whitt, E. (2016). McNair scholars' science, technology, engineering, and mathematics (STEM) graduate experience: A pilot study. Mid-Western Educational Researcher, 28(1). http:/www.mwera.org/MWER/volumes/v28/issue1/v28n1-BancroftFEATURE-ARTICLE.pdf

Barbour, R. S. (2001). Checklists for improving rigour in qualitative research: A case of the tail wagging the dog? BMJ: British Medical Journal, 322(7294), 1115. http://dx.doi.org/10.1136/bmj.322.7294.1115

Baum, S., \& Steele, P. (2017). Who goes to graduate school and who succeeds? Washington, DC: Access Group. https://www.urban.org/research/publication/who-goes-graduate-schooland-who-succeeds

Booth, A., Sutton, A., \& Papaioannou, D. (2012). Systematic approaches to a successful literature review. London: SAGE.

Braun, V., \& Clarke, V. (2006). Using thematic analysis in psychology. Qualitative Research in Psychology, 3, 77-101. doi:10.1191/1478088706qp063oa

Byrd-Johnson, L. (2017). Applications for new awards: Ronald E. McNair Postbaccalaureate Achievement Program. Retrieved from: https:/www.federalregister.gov/documents/2017/02/21/201703366/applications-for-new-awards-ronald-e-mcnair-postbaccalaureateachievement-program

Carter, D. F. (2006). Key issues in the persistence of underrepresented minority students. New Directions for Institutional Research, (130), 33-46.

Corcoran, R. (2017). Independent evaluation in educational research. Retrieved from https://irinstitutes.org/importance-independent-evaluationeducational-interventions/

Council for Opportunity in Education (COE). (2017). COE Statement on White House proposal to eliminate Ronald E. McNair Post-baccalaureate 


\section{Higher Education Politics \& Economics}

Achievement and Education Opportunity Centers TRIO programs.

Retrieved from: http://www.coenet.org/press_releases_052317.shtml

Cruz, I. (2015). Reimagining the Ronald E. McNair Scholars Program through the lens of intellectual entrepreneurship. Planning for Higher Education, 43(2), 33-39.

Davies, D., \& Dodd, J. (2002). Qualitative research and the question of rigor. Qualitative Health Research, 12(2), 279-289. http://dx.doi.org/10.1177/104973230201200211

Davis, D. J. (2010). The academic influence of mentoring upon African American undergraduate aspirants to the professoriate. The Urban Review, 42(2), 143-158. https://doi.org/10.1007/s11256-009-0122-5

Dixon-Woods, M., \& Sutton, A. (2003). Systematic review. In M. Lewis-Beck, A. E. Bryman, \& T. F. Liao (Eds.) SAGE Encyclopedia of Social Science Research Methods (Vol. 3, pp. 1110-1111). Thousand Oaks, CA: SAGE.

Dixon-Woods, M., Agarwal, S., Jones, D., Young, B., \& Sutton, A. (2005). Synthesizing qualitative and quantitative evidence: A review of possible methods. Journal of Health Services Research \& Policy, 10(1), 45-53.

Engle, J. (2007). Postsecondary access and success for first-generation college students. American Academic, 3(1), 25-48.

Ethington, C. A., \& Smart, J. C. (1986). Persistence to graduate education. Research in Higher Education, 24(3), 287-303.

http://dx.doi.org/10.1007/BF00992076

Fifolt, M., Engler, J., \& Abbott, G. (2014). Bridging STEM professions for McNair Scholars through faculty mentoring and academic preparation. College and University, 89(3), 24-33.

Freeman, M., DeMarrais, K., Preissle, J., Roulston, K., \& St. Pierre, E. A. (2007). Standards of evidence in qualitative research: An incitement to discourse. Educational Researcher, 36(1), 25-32. http://dx.doi.org/10.3102/0013189X06298009

Gallardo, G. E. (2009). The Ronald E. McNair Post-baccalaureate Achievement Program. Black Collegian, 39(2), 64-71.

Gittens, C. B. (2014). The McNair program as a socializing influence on doctoral degree attainment. Peabody Journal of Education, 89(3), 368-379. https://doi.org/10.1080/0161956X.2014.913450

Graham, L. (2011). Learning a new world: Reflections on being a first-generation college student and the influence of TRIO programs. New Directions for Teaching and Learning, 2011(127), 33-38. https://doi.org/10.1002/tl.455

Greene, K. (2007). Alumni perceptions of the McNair scholars program at Kansas universities (Doctoral dissertation). Retrieved from ProQuest.

Grimmett, M. A. S., \& Bliss, J. R. (1998). Assessing federal TRIO McNair program participants' expectations and satisfaction with projects. Journal of Negro Education, 67(4), 404.

Hammersley, M. (2003). Literature Review. In M. Lewis-Beck, A. E. Bryman, \& T. F. Liao (Eds.) SAGE Encyclopedia of Social Science Research Methods (Vol. 2, pp. 577-578). Thousand Oaks, CA: SAGE. 
Hammersley, M. (2007). The issue of quality in qualitative research. International Journal of Research \& Method in Education, 30(3), 287-305. http://dx.doi.org/10.4135/9780857024565.d11

Huerta, A. L. (2013). First-generation college students and undergraduate research: Narrative inquiry into the University of Arizona's Ronald E. McNair Achievement Program and the phenomenon of student transformation (Unpublished doctoral dissertation). University of Arizona, Tucson.

Humphrey, J., Carey, N., \& Mansfield, W. (2002). A profile of the Ronald E. McNair Post-baccalaureate Achievement Program: 1999-2000. Mathematica Policy Research. Retrieved from https://ideas.repec.org/p/mpr/mprres/bae10815e27d4033aa413b9e31d0eac 0. html

Ishiyama, J. T., \& Hopkins, V. M. (2003). Assessing the impact of the McNair Program on students at a public liberal arts university. Opportunity Outlook, 20-24.

Jean, R. (2011). Bootstraps: Federal TRIO programs, if funded, could help close income gap. New England Journal of Higher Education. Retrieved from http://www.nebhe.org/thejournal/bootstraps-federal-trio-programs-iffunded-could-help-close-income-gap/

Jones, M. T., Barlow, A. E., \& Villarejo, M. (2010). Importance of undergraduate research for minority persistence and achievement in biology. The Journal of Higher Education, 81(1), 82-115.

http://dx.doi.org/10.1080/00221546.2010.11778971

King, S. E., \& Chepyator-Thomson, J. R. (1996). Factors affecting the enrollment and persistence of African-American doctoral students. Physical Educator, 53(4), 170-180.

Kim, Y. M. (2011). Minorities in higher education (24th ed.). Washington, D.C.: American Council on Education. https://diversity.ucsc.edu/resources/images/ace_report.pdf

Kniffin, K. M. (2007). Accessibility to the PhD and professoriate for firstgeneration college graduates: Review and implications for students, faculty, and campus policies. American Academic, 3, 49-79.

MacPhee, D., Farro, S., \& Canetto, S. S. (2013). Academic self-efficacy and performance of underrepresented STEM majors: Gender, ethnic, and social class patterns. Analyses of Social Issues and Public Policy, 13(1), 347-369. http://dx.doi.org/10.1111/asap.12033

Mansfield, W., Sargent, K. D., Cahalan, M. W., Belle, R. L., Jr, \& Bergeron, F. (2002). A profile of the Ronald E. McNair Post-baccalaureate Achievement Program: 1998-99 with selected data from 1997-98 and 1996-97. Mathematica Policy Research. Retrieved from https://ideas.repec.org/p/mpr/mprres/fd1c5b2f63fd437cae85f7382136959b. html

McCoy, A., Wilkinson, A., Jackson, R. (2008). Educational and employment outcomes of Ronald E. McNair Post-Baccalaureate Achievement Program alumni. US Department of Education, Office of Planning, Evaluation. and 


\section{Higher Education Politics \& Economics}

Policy Development, Policy and Program Studies Service.

https://www2.ed.gov/rschstat/eval/highered/mcnair/mcnair.pdf

National Academy of Sciences, National Academy of Engineering, and Institute of Medicine. (2011). Expanding underrepresented minority participation: America's science and technology talent at the crossroads. Washington, DC: The National Academies Press. https://doi.org/10.17226/12984.

National Center for Educational Statistics. (n.d.). Integrated Postsecondary Education Data System. [Data file]. Retrieved from https://nces.ed.gov/ipeds/

National Science Foundation, National Center for Science and Engineering Statistics. 2017. Doctorate Recipients from U.S. Universities: 2015. Special Report NSF 17-306. Arlington, VA. Retrieved from https://www.nsf.gov/statistics/2017/nsf17306/.

Nnadozie, E., Ishiyama, J., \& Chon, J. (2001). Undergraduate research internships and graduate school success. Journal of College Student Development, $42(2), 145$.

Office of Postsecondary Education. (2016). Funding status. Retrieved from https://www2.ed.gov/programs/triomcnair/funding.html

Office of Postsecondary Education. (2017a). Federal TRIO programs home page. Retrieved from https://www2.ed.gov/about/offices/list/ope/trio/index.html

Office of Postsecondary Education. (2017b). Frequently asked questions. Retrieved from https://www2.ed.gov/programs/triomcnair/faq.html\#q8

Office of Postsecondary Education. (2017c). Purpose. Retrieved from https://www2.ed.gov/programs/triomcnair/index.html

Office of the Press Secretary. (2017). Off-camera briefing of the FY18 budget by office of management and budget Director Mick Mulvaney. Retrieved from https://www.whitehouse.gov/the-press-office/2017/05/22/camera-briefingfy18-budge-omb-director-mulvaney

Okahana, H., Feaster, K., \& Allum, J. (2016). Graduate enrollment and degrees: 2005 to 2015. Washington, DC: Council of Graduate Schools. https://cgsnet.org/ckfinder/userfiles/files/Graduate\%20Enrollment $\% 20 \% 20$ Degrees\%20Fall\%202015\%20Final.pdf

Olive, T. (2010). Desire for higher education in first-generation Hispanic college students. International Journal of Interdisciplinary Social Sciences, 5(1), 377-389. http://dx.doi.org/10.18848/1833-1882/CGP/v05i01/53091

Ong, M., Wright, C., Espinosa, L., \& Orfield, G. (2011). Inside the double bind: A synthesis of empirical research on undergraduate and graduate women of color in science, technology, engineering, and mathematics. Harvard Educational Review, 81(2), 172-209. http://dx.doi.org/10.17763/haer.81.2.t022245n7x4752v2

Parker, K. D. (2003). Achieving diversity in graduate education: Impact of the Ronald E. McNair Post-baccalaureate Achievement Program. Negro Educational Review, 54(1), 47-50.

Posselt, J. R., \& Black, K. R. (2012). Developing the research identities and aspirations of first-generation college students. International Journal for 
Researcher Development; Leeds, 3(1), 26-48. https://doi.org/http://dx.doi.org/10.1108/17597511211278634

Renbarger, R., \& Beaujean, A. A. (2020). A meta-analysis of graduate school enrollment from stu-dents in the Ronald E. McNair Post-Baccalaureate Program. Education Sciences, 10(1), 1-15.

Seburn, M., Chan, T., Kirshstein, R. (2005). A profile of the Ronald E. McNair Postbaccalaureate Achievement Program, 1997-1998 through 2001-2002. US Department of Education, Office of Postsecondary Education. https://www2.ed.gov/programs/triomcnair/mcnairprofile1997-2002.pdf

Smith, B. (2013). Mentoring at-risk students through the hidden curriculum of higher education. Lexington Books.

Smith, J. K., \& Hodkinson, P. (2005). Relativism, criteria, and politics. In N. K. Denzin \& Y. S. Lincoln (Eds.), The SAGE handbook of qualitative research (3rd ed., pp. 915-932).

Sowell, R., Allum, J., \& Okahana, H. (2015). Doctoral initiative on minority attrition and completion. Washington, DC: Council of Graduate Schools. https://cgsnet.org/ckfinder/userfiles/files/DIMAC_2015_final_report_PR.p df

Sparkes, A. C., \& Smith, B. (2009). Judging the quality of qualitative inquiry: Criteriology and relativism in action. Psychology of Sport and Exercise, 10(5), 491-497. http://dx.doi.org/10.1016/j.psychsport.2009.02.006

Sverdlik, A., Hall, N. C., McAlpine, L., \& Hubbard, K. (2018). The PhD experience: A review of the factors influencing doctoral students' completion, achievement, and well-being. International Journal of Doctoral Studies, 13, 361-388. https://doi.org/10.28945/4113

Thayer, P. B. (2000). Retention of students from first generation and low income backgrounds. Council for Opportunity in Education, 1025 Vermont Ave. Retrieved from http://www.pellinstitute.org/downloads/trio_clearinghouseThayer_May_2000.pdf

Thomas, E. P. (1994). Taking the first steps toward graduate education: A report on the Ronald E. McNair Postbaccalaureate Achievement Program. OCLC: 425262026. Retrieved from ERIC. https://eric.ed.gov/?id=ED440588

Thomas, J., \& Harden, A. (2008). Methods for the thematic synthesis of qualitative research in systematic reviews. BMC Medical Research Methodology, 8(1), 45. https://doi.org/10.1186/1471-2288-8-45

Tinto, V. (2012). Leaving college: Rethinking the causes and cures of student attrition. Chicago, IL: University of Chicago Press.

Tracy, S. J. (2010). Qualitative quality: Eight "big-tent" criteria for excellent qualitative research. Qualitative Inquiry, 16(10), 837-851. http://dx.doi.org/10.1177/1077800410383121

RACHEL RENBARGER, is a Ph.D. Candidate at Baylor University. Her research interests include best practices in providing supports for high-achieving and underserved student groups in K-12 and postsecondary settings. Email: RachelRenbarger@Gmail.com 